\title{
PENGARUH IMBANGAN KONSENTRAT DENGAN JERAMI UREA KAPUR MOLASIS DALAM RANSUM KAMBING TERHADAP KECERNAAN, METABOLIT RUMEN, DAN KIMIA DARAH
}

\author{
CAKRA, I G. L. O., A. A. A. S. TRISNADEWI, DAN I W. WIRAWAN \\ Program Studi Peternakan, Fakultas Peternakan, Universitas Udayana, \\ e-mail: oka_cakra@unud.ac.id
}

\begin{abstract}
ABSTRAK
Penelitian untuk mengetahui pengaruh imbangan konsentrat dengan jerami urea kapur dan molasis (JUKM) dalam ransum terhadap kecernaan, kadar metabolit rumen dan kimia darah, telah dilakukan pada kambing peranakan etawah dengan menggunakan rancangan bujur sangkar latin $4 \times 4$. Perlakuan yang diberikan adalah perlakuan A (JUKM 60\% dan konsentrat 40\%) perlakuan B (JUKM 50\% dan konsentrat 50\%), perlakuan C (JUKM $40 \%$ dan konsentrat 60\%), perlakuan D (JUKM 30\% dan konsentrat 70\%). Peubah yang diamati adalah konsumsi bahan kering jerami dan konsentrat, koefesien cerna, kadar kimia darah, kadar metabolit dan populasi protozoa rumen. Hasil penelitian ini mendapatkan, penggunaan konsentrat 40-70\% dalam ransum JUKM menunjukkan hasil yang berbeda tidak nyata terhadap konsumsi bahan kering, kadar glukosa dan $\mathrm{N}$ urea plasma darah. Terjadi peningkatan kecernaan nutrien, kadar trigliserida, total protein dan kolesterol darah seiring dengan meningkatnya tingkat penggunaan konsentrat. Dari hsil penelitian dapat disimpulkan bahwa penggunaan JUKM sebagai pakan serat dalam ransum ternak kambing sampai pada tingkat penggunaan 60\% dari keperluan bahan kering, tidak berpengaruh terhadap konsumsi bahan kering, kadar glukosa dan $\mathrm{N}$ urea plasma darah.
\end{abstract}

Kata kunci: konsentrat, jerami urea kapur molasis, kecernaan, metabolit rumen, kimia darah

\section{THE EFFECT OF CONCENTRATED BALANCE WITH UREA-LIME-M OLASSES STRAW ON DIGESTIBILITY, RUMEN METABOLITES AND BLOOD CHEMICAL OF ETAWAH GOAT BREED}

\begin{abstract}
The research aims to determine the effect of oncentrate balance with urea lime molasses straw (ULMS) on the digestibility, rumen metabolite levels, and blood chemistry has been carried out on Etawah crossbreed goats using a $4 \times 4$ latin square design. Treatment A (ULMS 60\% and concentrate 40\%), B (ULMS 50\% and concentrate 50\%), C (ULMS 40\% and concentrate 60\%), and D (ULMS 30\% and concentrate 70\%), were used to carry out this research. The observed variables were consumption of straw and, concentrate, digestibility coefficient, blood chemical levels, rumen metabolites, and rumen microbial population. The results showed that the use of $40-70 \%$ concentrate in the Urea-lime-molasses straw ration was insignificantly different from the consumption of dry matter, glucose levels, and blood plasma $\mathrm{N}$ urea. Furthermore, there was an increase in nutrient digestibility, triglyceride, total protein, and blood cholesterol, along with the increasing concentrate usage levels. It can be concluded that the use of ULMS as source of fiber of goat up to $60 \%$ from dry matter requirenment had no significant different in the consumption of dry matter, glucose levels, and blood plasma $\mathrm{N}$ urea.
\end{abstract}

Key words: concentrate, urea-lime-molasses-straw, digestibility, rumen metabolites, blood chemical

\section{PENDAHULUAN}

Jerami padi (Oriza sativa) merupakan limbah pertanian yang berpotensi sebagai sumber pakan alternatif pengganti hijauan segar. Berdasarkan luas tanaman pangan di Indonesia, maka total produksi padi
Indonesia tahun 2007 mencapai 56,54 juta ton dari luas lahan yang dipanen 10.9 juta hektare (BPS 2018). Setiap kg padi yang dipanen dihasilkan $0.8-1 \mathrm{~kg}$ jerami (Devendra 1997; Nguyen 1998) maka pada tahun 2018 Indonesia menghasilkan sekitar 56,54 juta ton jerami berdasar bahan kering. Apabila diasumsikan satu unit 
ternak (UT) setara dengan sapi dewasa berbobot tubuh $325 \mathrm{~kg}$ dan konsumsi bahan keringnya 2\% dari bobot tubuhnya (Madyono \& Anggraeny 2008), maka jerami padi yang tersedia dapat menampung 8,6 juta UT.

Pemanfaatan jerami padi secara langsung sebagai pakan tunggal tidak dapat memenuhi kebutuhan nutrisi pada ternak. Faktor-faktor yang menghambat penggunaan jerami padi sebagai pakan ternak ruminansia antara lain rendahnya kandungan zat makanan, nilai kecernaan maupun palatabilitasnya. Hal ini disebabkan tanaman padi yang dipanen pada umur tua mempunyai kandungan dinding sel yang tinggi dan tingkat lignifikasi yang sempurna sehingga sulit dirombak oleh mikroba rumen (Wardhani dkk., 1983). Salah satu upaya yang dapat dilakukan adalah dengan meningkatkan peran mikroba melalui penyediaan nutrisi terutama amonia, sehingga dapat meningkatkan kecernaan jerami padi. Suplementasi urea dapat digunakan sebagai sumber amonia (nitrogen), tetapi urea sangat cepat melepas nitrogen $(\mathrm{N})$ dalam rumen, dan dapat memproduksi amonia dengan cepat sehingga bila dosisnya berlebihan akan menyebabkan keracunan bahkan dapat menyebabkan kematian ternak (Stanton dan Whittier, 2006).

Penggunakan urea dalam ransum perlu disertai dengan penggunaan sumber energi (sumber karbohidrat) yang mudah larut/tersedia di dalam rumen, karena untuk mensintesa protein mikroba yang optimal diperlukan keseimbangan antara energi dalam bentuk volatile fatty acid (VFA) dan nitrogen dalam bentuk $\mathrm{N}^{-\mathrm{NH}_{3}}$. Suplementasi konsentrat diperlukan sebagai sumber protein dan energi dalam ransum. Untuk mendapatkan imbangan yang optimal antara $\mathrm{N}-\mathrm{NH}_{3}$ yang bersumber dari jerami urea kapur dan molasis (JUKM) dengan VFA yang bersumber dari konsentrat, maka dilakukan penelitian pengaruh imbangan antara konsentrat dengan jukm dalam ransum terhadap kecernaan, metabolit rumen dan kimia darah pada kambing peranakan etawah.

\section{MATERI DAN METODE}

\section{Tempat dan Lama Penelitian}

Penelitian dilakukan di tiga tempat: 1) di Desa Sidemen, Kecamatan Sidemen Kabupaten Karangasem, 2) di Laboratorium Nutrisi Ternak Fakultas Peternakan Universitas Udayana dan 3) Balai Penelitian Ternak Ciawi Bogor Jawa Barat. Penelitian dilakukan selama 3 bulan dengan masing-masing periode 3 minggu yang terdiri dari 2 minggu penyesuaian pakan dan 1 minggu pengambilan data.

\section{Pembuatan Campuran Jerami Urea Kapur Molasis (JUKM) dan Konsentrat}

Campuran urea kapur molasis terdiri dari urea $4 \%$, kapur $2 \%$ dan molasis 25\%, selanjutnya $69 \%$ jerami padi yang sudah kering matahari, dipotong potong dengan panjang sekitar 3-5 cm kemudian disebar merata dengan ketebalan $5 \mathrm{~cm}$. Campuran urea kapur molasis yang sudah dibuat sesuai dengan komposisinya disiramkan di atas tebaran jerami tadi. Konsentrat dibuat dari bahan bahan: dedak padi, polard, cassava, kacang kedele dan mineral pignox dengan kandungan protein kasar $15 \%$ dan Total digestible nutrient 59.

\section{Rancangan Percobaan}

Dalam penelitian ini menggunakan rancangan bujur sangkar latin (BSL) $4 \times 4$ dengan empat ransum perlakuan dan diulang empat kali (periode). Keempat ransum perlakuan adalah: perlakuan A (JUKM 60\% dan konsentrat 40\%), perlakuan B(JUKM 50\% dan konsentrat 50\%), perlakuan C (JUKM 40\% dan konsentrat 60\%), perlakuan D (JUKM 30\% dan konsentrat 70\%).

\section{Peubah yang Diamati}

Peubah yang diamati adalah koefesien cerna (bahan kering, bahan organik, protein, dan serat kasar), kadar metabolit rumen ( $\mathrm{pH}, \mathrm{VFA}, \mathrm{NH}_{3}$ dan populasi protozoa), dan kimia darah (glukosa, trigliserida, total protein, kolesterol dan N-urea darah).

\section{Pengukuran kecernaan dan pengambilan sampel}

Pengukuran kecernaan dilakukan dengan koleksi total dan masing-masing periode memerlukan waktu 3 minggu yang terdiri dari 2 minggu penyesuaian pakan dan 1 minggu koleksi total. Pengambilan sampel darah dan cairan rumen dilakukan pada akhir koleksi pada setiap periode. Pengambilan sampel cairan rumen menggunakan pompa pacum 4 jam setelah diberikan pakan. Sampel cairan rumen disaring dengan kain katun 4 lapis kemudian dibagi 2, satu bagian ditambahkan $\mathrm{H}_{2} \mathrm{SO}_{4}$, untuk pengukuran $\mathrm{NH}_{3}$ dan VFA. Satu bagian lagi ditambahkan MFS (Metyl green Formaline Salin) (Galyean, 1989), untuk menghitung populasi protozoa. Nilai pH cairan rumen diukur sebelum disaring dengan pH meter merek Orion series 200. Sampel darah diambil dari vena jugularis dengan tabung heparin sekitar 3 $\mathrm{ml}$ sesaat setelah pengambilan cairan rumen. Sampel darah segera dibawa ke laboratorium untuk dilakukan penanganan.

\section{Analisis Data}

Data yang diperoleh dianalisis dengan sidik ragam. Apabila terdapat hasil yang berbeda nyata $(\mathrm{P} \leq 0.05)$, analisis dilanjutkan dengan uji jarak berganda dari Duncan (Steel dan Torrie, 1986). 


\section{HASIL DAN PEMBAHASAN}

Hasil penelitian mendapatkan bahwa konsumsi bahan kering konsentrat rata-rata pada perlakuan A, B, C dan D secara berurutan adalah 360,83, 444,91, 546,92 dan 607,05 g/ekor/hari (Tabel 2). Secara statistik konsumsi konsentrat nyata $(\mathrm{P}>0.05)$ meningkat dari perlakuan A ke perlakuan D. Hal ini sesuai dengan perlakuan yang diberikan yaitu tingkat pemberian konsentrat meningkat dari perlakuan A ke perlakuan D. Konsumsi rata rata bahan kering JUKM pada perlakuan A, B, C dan D adalah 436,69; 368,89; 294,71 dan 176,93g/ekor/hari (Tabel 2). Secara statistik rata-rata konsumsi bahan kering JUKM nyata $(\mathrm{P}>0.05)$ menurun dari perlakuan A ke perlakuan D. Hal ini trjadi karena peningkatan konsumsi konsentrat diikuti dengan menurunnya konsumsi JUKM. Kenyataan ini terjadi karena pabila kebutuhan nutrisi sudah dipenuhi dari konsentrat maka walaupun pemberian JUKM diberikan secara ad-libitum maka ternak itu tidak akan makan lagi. Berbeda dengan perlakuan $\mathrm{C}$ dimana dengan adanya peningkatan imbangan konsentrat cendrung meningkatkan konsumsi bahan kering (Gambar 1).

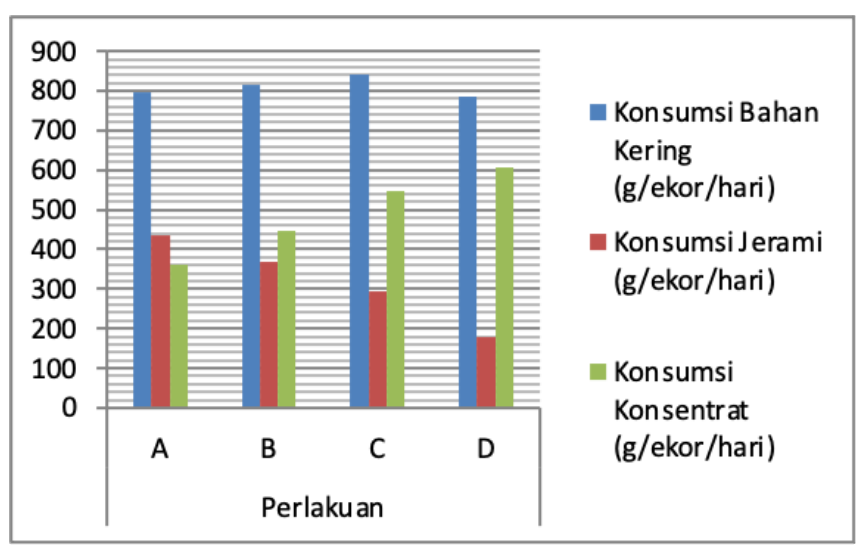

Gambar 1. Konsumsi bahan kering, jerami dan konsentrat

\section{Kecernaan bahan kering dan nutrien ransum}

Angka rataan kecernaan bahan kering pada perlakuan A, B, C dan D adalah 62,80, 69,54, 70,61, dan $75,06 \%$. Berdasarkan hasil uji statistik angka kecernaan bahan kering meningkat nyata dari perlakuan A ke D (Tabel 3). Peningkatan kecernaan bahan kering diikuti dengan peningkatan kecernaan (bahan organik, protein kasar, serat kasar dan lemak kasar), hal ini terjadi karena adanya peningkatan konsumsi konsentrat (Tabel 1). Konsentrat mengandung nutrisi yang lebih tinggi dibandingkan dengan JUKM, sehingga peningkatan konsumsi konsentrat akan dapat meningkatkan ketersediaan nutrisi bagi mikroba dan mikroba dapat melakukan pencernaan fermentatif sehingga dapat meningkatkan kecernan bahan kering dan nutrien ransum (Tabel 3).

\section{Kadar Metabolit Rumen}

Kadar metabolit rumen dapat digunakan sebagai petunjuk dalam melakukan evaluasi terhadap kualitas ransum yang dimakan oleh ternak. Kadar metabolit rumen (VFA dan $\mathrm{NH}_{3}$ nyata meningkat dari perlakuan A, B dan C. Hal ini terjadi karena adanya peningkatan penggunaan konsentrat dalam ransum. Konsentrat merupakan bahan pakan yang mengandung karbohidrat mudah larut yang tinggi sehingga dapat meningkatkan kadar VFA dalam cairan rumen. Demikian juga halnya dengan meningkatnya kadar $\mathrm{NH}_{3}$ sebagai akibat dari meningkatnya kandungan protein ransum sebagai akibat adanya peningkatan level konsentrat (Tabel 4). Berbeda dengan angka $\mathrm{pH}$ dan populasi protozoa, angka rataan tidak berbeda nyata antar perlakuan. Hal ini menunjukkan bahwa keasaman rumen tidak dipengaruhi dengan adanya perbedaan imbangan antara JUKM dengan konsentrat dalam ransum. Populasi protozoa antar perlakuan tidak berbeda nyata, hal ini menunjukan bahwa imbangan konsentrat $40 \%$ dan JUKM 60\% sudah cukup untuk pertumbuhan mikroba terutama protozoa rumen

\section{Kimia Darah}

Rataan kadar N urea darah pada perlakuan A, B, C dan D adalah 25,5, 27,1, 28,o dan 30,45 mg/dL (Tabel 5), secara statistic didapatkan berbeda tidak nyata antar perlakuan. Hal ini menunjukkan bahwa pemberian konsentrat 40\% pada perlakuan A sampai

Tabel 1. Pengaruh tingkat imbangan konsentrat dengan JUKM terhadap konsumsi

\begin{tabular}{|c|c|c|c|c|}
\hline \multirow{2}{*}{ Variabelkonsumsi } & \multicolumn{4}{|c|}{ Perlakuan $^{1)}$} \\
\hline & $A$ & B & $\mathrm{C}$ & D \\
\hline Bahan kering (g/ekor/hari) & $797,52 \pm 106,94^{a}$ & $813,80 \pm 100,33^{a}$ & $841,63 \pm 166,78^{a}$ & $783,98 \pm 168,40^{a}$ \\
\hline Bahan kering $\left(\mathrm{g} / \mathrm{W}^{0,75}\right)$ & $64,83 \pm 12,87^{a}$ & $64,58 \pm 17,28^{a}$ & $64,73 \pm 14,89^{a}$ & $59,25 \pm 6,43^{a}$ \\
\hline JUKM (g/ekor/hari) & $436,69 \pm 75,64^{a}$ & $368,89 \pm 64,06^{b}$ & $294,71 \pm 32,78^{c}$ & $176,93 \pm 38,03^{d}$ \\
\hline Jerami $\left(g / W^{0,75}\right)$ & $35,46 \pm 7,96^{a}$ & $29,25 \pm 8,27^{b}$ & $22,59 \pm 2,71^{\mathrm{c}}$ & $13,39 \pm 2,00^{d}$ \\
\hline Konsentrat (g/ekor/hari) & $360,83 \pm 40,31 \mathrm{~d}$ & $444,91 \pm 61,05^{c}$ & $546,92 \pm 138,05^{b}$ & $607,05 \pm 145,91^{a}$ \\
\hline Konsentrat $\left(\mathrm{g} / \mathrm{W}^{0,75}\right)$ & $29,38 \pm 5,66^{d}$ & $35,33 \pm 0,89^{c}$ & $42,14 \pm 12,26^{b}$ & $45,86 \pm 6,64^{a}$ \\
\hline
\end{tabular}

Keterangan:

1) Perlakuan A (JUKM 60\% dan konsentrat 40\%). Perlakuan B (JUKM 50\% dan konsentrat 50\%), Perlakuan C (JUKM $40 \%$ dan konsentrat $60 \%$ ), dan Perlakuan D (JUKM $30 \%$ dan konsentrat $70 \%)$

2) Nilai dengan huruf yang sama pada baris yang sama menunjukkan berbeda tidak nyata $(P>0,05)$ 
Tabel 2. Pengaruh tingkat pemberian imbangan konsentrat dengan JUKM terhadap kecernaan nutrien

\begin{tabular}{|c|c|c|c|c|}
\hline \multirow{2}{*}{ Peubah } & \multicolumn{4}{|c|}{ Perlakuan ${ }^{1)}$} \\
\hline & A & B & C & D \\
\hline Kecernaan bahan kering (\%) & $62,80 \pm 1,11^{d}$ & $69,54 \pm 2,78^{c}$ & $70,61 \pm 6,09^{b}$ & $75,06 \pm 4,01^{a}$ \\
\hline Kecernaan bahan organik (\% BK) & $66,46 \pm 0,70^{d}$ & $72,64 \pm 2,37^{c}$ & $75,70 \pm 5,10^{b}$ & $80,76 \pm 3,47$ a \\
\hline Kecernaan protein kasar (\% BK) & $68,87 \pm 0,57^{d}$ & $74,35 \pm 2,08^{c}$ & $77,42 \pm 4,85 b$ & $84,89 \pm 2,52 \mathrm{a}$ \\
\hline Kecernaan serat kasar (\% BK) & $56,66 \pm 2,20^{d}$ & $66,98 \pm 3,38^{c}$ & $67,70 \pm 6,54^{b}$ & $68,12 \pm 6,32$ a \\
\hline Kecernaan lemak kasar (\% BK) & $68,88 \pm 0,57^{d}$ & $74,34 \pm 2,08^{c}$ & $77,42 \pm 4,85^{b}$ & $84,89 \pm 2,52$ a \\
\hline
\end{tabular}

Keterangan:

1) Perlakuan A (JUKM 60\% dan konsentrat 40\%). Perlakuan B (JUKM 50\% dan konsentrat 50\%), Perlakuan C (JUKM $40 \%$ dan konsentrat $60 \%$ ), dan Perlakuan D (JUKM $30 \%$ dan konsentrat $70 \%)$

2) Nilai dengan huruf yang sama pada baris yang sama menunjukkan berbeda tidak nyata $(P>0,05)$

Tabel 3. Pengaruh imbangan jukm engan konsentrat terhadap populasi protozoa dan metabolit rumen

\begin{tabular}{|c|c|c|c|c|}
\hline \multirow{2}{*}{ Variabel } & \multicolumn{4}{|c|}{ Perlakuan } \\
\hline & $A$ & B & $\mathrm{C}$ & $\mathrm{D}$ \\
\hline pH Cairan rumen & $6,88 \pm 0,13^{a}$ & $6,76 \pm 0,03^{a}$ & $6,78 \pm 0,05^{a}$ & $6,76 \pm 0,06^{a}$ \\
\hline Populasi protozoa sel/ml $\left(\log ^{10}\right)$ & $5,42 \pm 0,04^{a}$ & $5,48 \pm 0,07^{a}$ & $5,56 \pm 0,09^{a}$ & $5,60 \pm 0,06^{a}$ \\
\hline VFA total $(\mathrm{mM}) / \mathrm{L}$ & $90,97 \pm 18,38^{d}$ & $114,83 \pm 4,40^{c}$ & $112,88 \pm 8,20^{b}$ & $131,97 \pm 6,95^{a}$ \\
\hline $\mathrm{NH}_{3}$ rumen $(\mathrm{mM}) / \mathrm{L}$ & $7,90 \pm 1,14^{c}$ & $10,37 \pm 0,80^{b}$ & $14,52 \pm 2,07^{a}$ & $17,06 \pm 3,02^{a}$ \\
\hline
\end{tabular}

Keterangan:

1) Perlakuan A (JUKM 60\% dan konsentrat 40\%). Perlakuan B (JUKM 50\% dan konsentrat 50\%), Perlakuan C (JUKM $40 \%$ dan konsentrat $60 \%$ ), dan Perlakuan D (JUKM $30 \%$ dan konsentrat $70 \%)$

2) Nilai dengan huruf yang sama pada baris yang sama menunjukkan berbeda tidak nyata $(P>0,05)$

Tabel 4. Pengaruh Tingkat pemberian imbangan Konsentrat dengan JUKM terhadap kadar kimia plasma darah

\begin{tabular}{|c|c|c|c|c|}
\hline \multirow{2}{*}{ Variabel } & \multicolumn{4}{|c|}{ Perlakuan } \\
\hline & A & $\mathrm{B}$ & $\mathrm{C}$ & $\mathrm{D}$ \\
\hline BUN (mg/dL) & $25,50 \pm 3,15^{a}$ & $27,10 \pm 3,26^{a}$ & $28,00 \pm 4,62^{a}$ & $30,45 \pm 7,74^{a}$ \\
\hline Glukosa (mg/dL) & $82,45 \pm 6,55^{a}$ & $81,90 \pm 10,73^{a}$ & $77,20 \pm 14,39^{a}$ & $77,68 \pm 6,37^{a}$ \\
\hline Trigliserida (mg/dL) & $19,25 \pm 7,27^{d}$ & $20,75 \pm 5,85^{c}$ & $22,75 \pm 6,65^{b}$ & $27,50 \pm 3,00^{a}$ \\
\hline Total Protein (g/dL) & $6,97 \pm 0,68^{d}$ & $7,22 \pm 0,69^{c}$ & $7,91 \pm 1,06^{b}$ & $8,40 \pm 0,98^{a}$ \\
\hline Kolesterol darah (mg/dL) & $116,00 \pm 15,12^{a}$ & $82,50 \pm 9,57^{c}$ & $83,25 \pm 2,50^{b}$ & $77,25 \pm 4,11 \mathrm{bd}$ \\
\hline
\end{tabular}

Keterangan:

1) Perlakuan A (JUKM 60\% dan konsentrat 40\%). Perlakuan B (JUKM 50\% dan konsentrat 50\%), Perlakuan C (JUKM $40 \%$ dan konsentrat $60 \%$ ), dan Perlakuan D (JUKM $30 \%$ dan konsentrat $70 \%)$

2) Nilai dengan huruf yang sama pada baris yang sama menunjukkan berbeda tidak nyata $(P>0,05)$

70\% pada perlakuan D Kandungan $\mathrm{N}$ ureanya tidak berbeda nyata. Ini memberikan petunjuk bahwa penggunaan jerami urea kapur molasis sampai 60\% dalam ransum menghasilkan kadar $\mathrm{N}$ urea yang tidak berbeda nyata dengan perlakuan $\mathrm{D}$ dengan imbangan JUKM 30\% dan konsentrat 70\%. Konsentrasi urea darah yang tinggi membuat ternak tidak efisien dalam memanfaatkan energi yang dikonsumsinya (Roseler et al., 1993). Penelitian Manu (2007) pada kambing kadar urea darah normal antara 13 - $44 \mathrm{mg}$ / dL. Penggunaan energi yang dikonsumsi tidak efisien karena kadar urea darah yang tinggi (Roseler et al., 1993). Untuk mengubah konsentrasi amonia rumen menjadi amonia darah membutuhkan sumber energi yang besar kemudian dilanjutkan dalam bentuk urea dalam urin (Purbowati, 2007). Demikian juga halnya dengan kadar glukosa darah yang datanya sejalan dengan kadar $\mathrm{N}$ urea. Glukosa Plasma darah pada penelitian ini berkisar antara 77.2 - $82.4 \mathrm{mg} / \mathrm{dL}$, lebih tinggi dari Yupardhi et al. (2014), bahwa kadar glukosa darah kambing berada pada 64,67 mg / dL.

Kadar trigliserida plasma darah pada perlakuan
A, B, C dan D adalah: 19.25, 20.75, 22.75, 27,5 mg/dL (Tabel 5). Berdasarkan analisis ragam kadar trigliserida meningkat nyata $(\mathrm{P}>0,05)$ dari perlakuan $\mathrm{A}, \mathrm{B}, \mathrm{C}$ dan D. Hal ini terjadi karena adanya pemberian konsentrat yang meningkat dari perlakuan A, B, C dan D. Hal ini memberi petunjuk bahwa peningkatan pemberian konsentrat akan terjadi penyerapan nutrient yang dapat disimpan dalam bentuk trigliserida. Gagah et al. (2016), the lipid content in the blood of ruminants is influenced by the feed given, if the feed consumed contains good nutrients will produce higher triglyceride values. Triglycerides are one of the body's energy reserves. The body will remodel triglycerides into energy if the energy in the feed does not meet the body's energy needs (Cunningham, 2002).

Total protein plasma darah pada perlakuan A, B, $\mathrm{C}$ dan D adalah: 6,97, 7,22, 7,91 dan 8,40 g/dL (Tabel 5). Analisis statistic dengan sidik ragam mendapatkan bahwa rataan total protein dari perlakuan A, B, C dan D nyata $(\mathrm{P}>0,05)$ meningkat. Peningkatan ini dipengaruhi oleh tingkat pemberian konsentrat yang mengandung protein. Makin tinggi tingkat pemberian konsentrat 
maka penyerapannya juga meningkat sehinggga kadar total protein darah juga meningkat.

Rataan kandungan kolesterol darah pada perlakuan A, B, C dan D adalah: 77,25, 82,5, 83,25, dan 116,0 $\mathrm{mg} / \mathrm{dL}$ (Tabel 5). Berdasarkan analisis statistik rataan kandungan kolesterol darah nyata meningkat dari perlakuan A, B, C dan D. Peningkatan ini disebabkan oleh adanya pemberian konsentrat yang meningkat dari perlakuan A ke Perlakuan D, sehingga terjadi peningkatan penyerapan energi yang disimpan dalam bentuk lemak atau kolesterol. Cholesterol content with research Gagah et al. (2016), which is between $58-81$ $\mathrm{mg} / \mathrm{dL}$.

\section{SIMPULAN}

Dari hasil penelitian ini dapat disimpulkan bahwa penggunaan konsentrat 40-70\% dalam ransum Jerami Urea Kapur Molasis menunjukkan hasil yang berbeda tidak nyata terhadap konsumsi bahan kering, kadar glukosa dan $\mathrm{N}$ urea plasma darah. Terjadi peningkatan kadar trigliserida, total protein dan kolesterol darah seiring dengan meningkatnya tingkat penggunaan konsentrat.

\section{UCAPAN TERIMAKASIH}

Penelitian ini sepenuhnya didanai oleh Lembaga Penelitian dan Pengabdian Kepada Masyarakat Universitas Udayana, untuk itu melalui kesempatan ini penulis menyampaikan ucapan terimakasih.

\section{DAFTAR PUSTAKA}

[Badan Pusat Statistik] BPS. 2018. Ringkasan Eksekutif Luas Panen dan Produksi Beras di Indonesia 2018. ISSN /ISBN: 978-602-438-237-7 Tanggal Rilis: 2018-12-21

Gagah, H.W., M. Yamin., H. Nuraini, dan A. Esfandiari 2016. Performans produksi dan profil metabolik darah domba garut dan jonggol yang diberi limbah tauge dan omega-3. Jurnal Veteriner. No. 2 :246256.

Galyean, M. 1989. Laboratory Procedure in Animal Nutrition Research. Department of Animal and Life Science. New Mexico state University, USA.

Madyono dan Anggraeny Y.N. 2008. Teknologi pakanmurah untuk pembibitan sapi potong di sentra padi. Buletin Sinar Tani Edisi 25 Juni-1 Juli 2008.

Manu, A. E., dan P. P. D. I. E. Baliarti. 2007. Suplementasi pakan lokal urea gula air multinutrien blok untuk meningkatkan kinerja induk bunting dan menyusui serta menekan kematian anak kambing bligon yang digembalakan di sabana Timor (Doctoral dissertation, [Yogyakarta]: Universitas Gadjah Mada)

Nguyen, X., M., Mo, and, C.X., 2001. Effects of treatment of rice straw with lime and/or urea on its chemical composition, in-vitro gas production and in-sacco degradation characteristics. Livest. Res. Rar. Develop. 13, 5-12

Preston T. R. and Leng R. A. 1987. Matching Ruminant Production System with Available Resources in the tropics and in the Sub-tropics. Penambul Books, armidale. Australia.

Preston, T. R.. 1995. Tropic Animal Feeding. A Manual For Research For Research Workers. Food and Agriculture Organization of United Nations, Rome. [cited 2019 Septembre 14]. Available from : URL : http://Fao.org./docrep/oo3/v9327e/v9327Eoo. HTM

Purbowati, E. dan P. P. D. I. E. Baliarti, 2007. Kajian perlemakan karkas domba lokal dengan pakan komplit dari jerami padi dan konsentrat pada bobot potong yang berbeda (Doctoral dissertation, Universitas Gadjah Mada).

Roseler, D. K., Ferguson, J. D., Sniffen, C. J., and Herrema, J. 1993. Dietary protein degradability effects on plasma and milk urea nitrogen and milk nonprotein nitrogen in Holstein cows. Journal of Dairy Science, 76(2), 525-534. https://doi. org/10.3168/jds.Soo22-0302(93)77372-5.

Stanton, T. L. and J. Whittier. 2006. Urea and NPN for cattle and sheep. http://www.ext.colostate.edu/Pubs/ Livestk/01608.html. [25-01-2011]

Steel, R. G. D. and Torrie, J.H. (1986) Principles and procedures of statistics. 2nd Edition, McGraw Hill Book Co. Inc., New York, 336-354.

Wardhani, N. K., A. MusoficdanSudijanto. 1983. Pengaruh berbagai bentuk potongan pucuk tebu sebagai sumber hijauan makanan ternak terhadap palatabilitas ransum. Proc. Pertemuan Ilmiah Ruminansia Besar BPPP Departemen Pertanian, Bogor.

Yupardhi, W. S., I. G. L. Oka, I. B. Mantra, I. N. Suyasa, dan I. G. Suranjaya. 2014. Gambaran darah kambing gembrong, kambing peranakan etawah, dan kambing kacang di Bali (Blood illustration of gembrong goat, etawah crossbred goat and kacang goat in Bali). Jurnal Veteriner, 15(4), 494-498. 